\title{
Genetic diversity of captive spotted paca (Agouti paca) from south east Brazil assessed by the RAPD-PCR technique ${ }^{1}$
}

\section{Karine Vieira Antunes ${ }^{2}$, Théa Mírian Medeiros Machado ${ }^{3}$, Nicola Vergara Lopes Serão ${ }^{4}$, Simone Eliza Facione Guimarães ${ }^{3}$, Samuel Rezende Paiva ${ }^{5}$}

\author{
1 Pesquisa financiada pela CAPES. \\ 2 Pós-Graduanda em Zootecnia da UFV - Viçosa, MG. \\ ${ }^{3}$ Departamento de Zootecnia da UFV - Viçosa, MG. \\ 4 Pós-Graduando em Genética e Melhoramento da UFV - Viçosa, MG. \\ ${ }^{5}$ Embrapa Recursos Genéticos e Biotecnologia - Brasília, DF.
}

ABSTRACT - The genetic diversity was analyzed among spotted paca (Agouti paca) from three commercial flocks located in Brazil. As the genome of this species is unknown, the RAPD-PCR technique was used. Ten primers generated sixty polymorphic bands. The among and within population genetic variability estimated by analysis of molecular variance (AMOVA) was 12.55 and $87.45 \%$, respectively. The shortest Nei distance value was $11.76 \%$ among the Carangola (CG) and São Francisco do Glória (SF) populations. This value can be explained by the exchange of reproduction males and females between the two geographically close breeding sites. The analysis of principal components showed well defined and structured groups aggregating animals according their population of origin, with some exceptions. Lower diversity was found in the São Francisco population than in the Carangola and Castelo (CS) populations. This result suggested the variability is better conserved in breeding farms with fifty or sixty animals (CG and CS) than in the breeding farm with a dozen animals (SF). The RADP-PCR technique proved to be informative for the quantification of among and within population genetic variability of the spotted paca. The phenogram generated by UPGMA using the NTSYS-PC software from the Nei Distance, grouped CG and SF on a single branch connected to the CS, with 76 and $100 \%$ accuracy, respectively, to the bootstrap. This result was not only consistent with the historical and geographical information on flocks, but also shows the need for periodic reproductive male replacement. Future studies should be developed with co-dominant markers and include spotted paca from more distant places.

Key Words: animal conservation, animal genetic resources, biodiversity, genetic distance, wild animals

\section{Diversidade genética da paca de cativeiro no Sudeste brasileiro avaliada por meio de marcadores RAPD-PCR}

\begin{abstract}
RESUMO - Estudou-se a diversidade genética de pacas (Agouti paca) de três plantéis comerciais no Brasil. Como o genoma desta espécie é desconhecido, utilizaram-se o polimorfismo de DNA amplificado ao acaso e reação em cadeia da polimerase (RAPD-PCR). Dez primers selecionados geraram 60 bandas polimórficas. A variabilidade genética inter e intrapopulações estimada pela análise de variância molecular (AMOVA) foi de 12,55 e 87,45\%, respectivamente. A menor distância de Nei encontrada foi de 11,76\% entre as populações de Carangola (CG) e São Francisco do Glória (SF). Este valor pode ser explicado pelo intercâmbio de matrizes e reprodutores que já ocorre entre esses dois criatórios geograficamente próximos entre si. Na análise dos componentes principais, foram observados grupos bem estruturados e definidos, agregando indivíduos à sua população de origem, com algumas exceções. A diversidade foi menor na população São Francisco que em Carangola e Castelo (CS). Esse resultado sugere que, em criatórios com 5 a 6 dezenas de animais (CG e CS), a variabilidade se mantém melhor que naquele com cerca de uma dúzia de animais (SF). A técnica de RAPD-PCR mostrou-se informativa para quantificar a variabilidade genética entre e intrapopulações de pacas. O fenograma gerado pelo método UPGMA por meio do programa NTSYS-PC a partir da distância de Nei agrupou CG e SF num mesmo ramo e este ligado ao CS, com acurácia de 76 e 100\%, respectivamente, ao bootstrap. Esse resultado condiz com as informações geográficas e o histórico dos rebanhos e mostra a necessidade de substituição periódica de machos reprodutores. Mais estudos devem ser desenvolvidos com marcadores codominantes e com pacas de localidades mais distintas.
\end{abstract}

Palavras-chave: animais silvestres, biodiversidade, conservação animal, distância genética, recursos genéticos animais 


\section{Introduction}

Wild animal breeding is an activity that requires little capital to be started, allows the use of marginal farm areas, generates products with high aggregated value and has low environmental impact. The products may supply both national and foreign markets using legal animals, thus lowering illegal hunting or animal traffic (Smythe \& Brown de Guanti, 1995; Nogueira filho \& Nogueira, 2000). Wild animal meat is rich in proteins and has a low caloric value (Paleari et al., 2003; Oda et al., 2004). The availability of bred wild animals allows the development of scientific research and the growth of the population at risk of extinction (Machado et al., 2007a, b).

Brazilian native wild animal breeding is permitted by Brazilian law in protection of wild animals (Brasil, 1967). Indications from IBAMA (Brazilian institute for environment and renewable natural resources) regulate the handling and ownership of wild animals in the country (IBAMA, 1977a,b; IBAMA, 2008a,b). The IBAMA regulations of 1997 for commercial breeding and commercialization increased the number of commercial breeding farms of wild animals with zootechnic potential (Machado et al., 2007 b). Until 2001 (last available census) in Brazil, there were: 2 scientific spotted paca breeding farms; 26 commercial ones and 5 conservationist ones (IBAMA, 2006a, b, c).

Spotted paca is hunted for its agreeable taste and because it damages fields (Deutsch \& Puglia, 1988). Its meat is the most preferred in the restaurants of the city of Manaus (Moreira \& Mac Donald, 1997) and its breeding in captivity serves to form stocks of animals to meet the market demand (Nogueira Filho \& Nogueira, 1999).

One of the problems found in small populations, both bred and natural, is the preservation of genetic variety. Endogamy and genetic drift affect characteristics associated to natural adaptation, such as fecundity and viability (Lande, 1988; Nicholas, 1999; Bowland et al., 2001).

RAPD-PCR (Random Amplified Polymorphic DNA PCR) can help to know the diversity and the genetic correlations; previous knowledge of the genetic sequence of the studied species is not needed, only a small amount of DNA is required for analysis and it is efficient and cheap (Welsh \& Mc Clelland, 1990; Williams et al., 1990; Hadrys et al., 1992).

The objectives of this study were to study the genetic diversity among spotted paca populations bred in captivity and to identify the first molecular markers for this species.

\section{Material and Methods}

A total of 81 animals was analyzed, chosen randomly (males, females, adults, young adults and juveniles) from three breeding farms in southeastern Brazil, in the states of Minas Gerais and Espirito Santo. In Minas Gerais, 13 animals were from a breeding farm in São Francisco da Gloria (SF) and 38 from Carangola (CG). In Espirito Santo, specimens were collected from 30 animals from a breeding farm in Castelo (CS). The first breeding farm (SF) was very small and the 13 animals analyzed were all the animals present; in the others at least 30 specimens were analyzed, representing 50 to $60 \%$ of the animals of the breeding farms.

Together with each collected sample, we recorded information such as the number of the sample among all the specimens and among those taken on that breeding farm; name of the breeding farm; city; box number; collector and date. As spotted paca are, even when bred, wild animals, we tried to develop the least stressful way to collect biological samples, reducing the stress of capture, containment and the operating time. We collected hairs (fur) from the back and hip of the animals, using surgical forceps. The collection of fur as biologic material to extract DNA is practical and economical, as hairs do not need any reagent or low storage temperatures.

The hairs were stored in properly identified paper bags with the name of the breeder and the animal identification number. The protocols for the DNA extraction, quantification and amplification were based on similar ones already used in our laboratory and described in the literature (Sambrock et al., 1989; Lima et al., 1998).

The extracted DNA was quantified by spectrophotometry (Gene Quant II RNA/DNA Calculator Pharmacia Biotec) and later diluted to the concentration of 50 nanograms/ microliter $(\mathrm{hg} / \mathrm{mL})$ and stored at $+4^{\circ} \mathrm{C}$. To set up the protocols of the RAPD-PCR reactions, several tests were performed using different concentrations of DNA or Magnesium Chloride ( $\mathrm{MgCl} 2)$ and different annealing temperatures, until well defined and reproductable bands were obtained. Twenty-four random primers were tested, produced by Operon Technologies (http://www.operon.com) to select those, which produced the highest number of best quality bands.

The PCR reactions were processed using a total volume of $13 \mu \mathrm{L}\left(4.5 \mu \mathrm{L}\right.$ of $\left.\mathrm{H}_{2} \mathrm{O}\right) ; 1.3 \mu \mathrm{L} 10 \mathrm{x}$ buffer $(150 \mu \mathrm{L}$ bidistilled water, $250 \mu \mathrm{L} 1$ molar KCl, $100 \mu \mathrm{L} 1$ molar Tris $\mathrm{HCl}$ pH 8.3, totaling $500 \mu \mathrm{L}$ ); $1.3 \mu \mathrm{L}$ primer (3 uM); 0,52 $\mu \mathrm{L}$ 
MgCl2 (50 mM), 1.04 $\mu \mathrm{L}$ dNTPs (2.5 mM), 1.04 $\mu \mathrm{L}$ BSA $(10 \mathrm{mg} / \mathrm{mL})$ and $0.3 \mu \mathrm{L}$ Taq DNA polymerase $(5 \mathrm{U} / \mu \mathrm{L})$ and $3 \mu \mathrm{L}$ DNA $10 \eta \mathrm{g} / \mu \mathrm{L}$. The following primers were used, identified as: OPA11, OPA16, OPB09, OPB11, OPB18, OPK20, OPN02, OPN20, OPS01 and OPS18 according to the following protocol: 3 minutes at $94^{\circ} \mathrm{C}$ for denaturation; 40 cycles of $94^{\circ} \mathrm{C}$ for 1 minute; $38^{\circ} \mathrm{C}$ for 1 minute for the annealing; $72^{\circ} \mathrm{C}$ for 1 minute for the extension and, after 40 cycles, 10 minutes at $72^{\circ} \mathrm{C}$ for the final extension. The amplified products were separated by electrophoresis in $10 \%$ polyacrilamide gel at 250 Volts. A molecular weight marker (1 Kb DNA ladder, Invitrogen Inc. CA) was used. Gel was developed by precipitation in silver nitrate gel. Polymorphic DNA bands were codified as 1 (presence) and 0 (absence) and organized as a binary matrix.

AMOVA (analysis of molecular variance) was to analyze the genetic structure, using the Arlequim v. 2 program that uses an AMOVA adaptation for dominants data, such as RAPD (Stewart Jr \& Excoffier, 1996; Schneider at al., 2000). The TFPGA v. 1.3 - Tools for population genetic analysis (Miller, 1997) was used for further among and within population analyses.

In the principal components analysis (PCA) the Jaccard similarity coefficent was used, suitable to the presence or absence of dominant markers, such as RAPD. The Nei genetic distance (1973) was used to construct the phenogram among the breeding farms, because it is indicated to study variability among geographically close populations that may have some degree of consanguinity (Weir, 1996). The UPGMA (Unweighted Pair Group Method With Arithmetric Mean, Sneath \& Sokal, 1973) was chosen to construct the dendrogram, as this method can be used with the most different coefficients of similarity, generates groups with minimal distortion and was widely tested for RAPD markers (Romesburg, 2004). The consensus phenogram was obtained from the bootstrap with 1,000 repetitions.

\section{Results and Discussion}

Ten of the 24 primers tested could amplify spotted paca DNA (41.7\%). This percentage was similar to that reported by Godoy et al. (2005) in ostriches, where they could select $38.9 \%$ of the primers according to the quality of the bands they produced. This result was lower than that obtained with water buffaloes (Albuquerque et al., 2006), wild boars and pigs (Gimenez et al., 2003), where 52.4 and $70.1 \%$ of the primers resulted in polymorphic fragments. This percentage was higher than that obtained in sheep, where $13.6 \%$ of the primers were functional (Paiva et al., 2005).
The 10 selected primers generated 105 bands, of which 60 were clearly polymorphic, from 298 to 2036 base pairs (pb). The average of 6.0 polymorphic bands for any amplifying primer is higher than the 3.0 obtained by Bouzat (2001) in great rhea; the 4.6 obtained by Albuquerque et al. (2006) in water buffaloes. It was similar to the 5.5 bands obtained by Serrano et al. (2004) in cattle and to the 5.8 obtained by Prim et al. (2003) in bullfrogs and was equal to that found by Godoy et al. (2005) in ostriches. The number of bands/primer was different from those found by Spritze et al. (2003) in Crioulo cattle; from Paiva et al. (2005), who found 2.8 bands/primer in Brazilian sheep and Gimenez et al. (2003), who find the highest number of bands/primer: 10.7 in wild boars, pigs and their hybrids and from Leipoldt et al. (1996), who found 22.5 bands/primer in lemurs.

The spotted pacas from the SF breeding farm generated two specific bands compared to those from the CS breeding farm. The CS breeding animals generated one specific band compared to the other two breeding farms and the spotted pacas from CG did not generate any specific band compared to the others breeding farms. These bands showed the difference among the analyzed populations and may be used to include or exclude specific specimens in one or the other population.

The genetic variability (Miller, 1997) within farm (Table 1) show that the animals from SF had the lowest genetic variability (GV) and the lowest percentage of polymorphic loci $(\mathrm{P})$ among the three breeding farms. This higher homogeneity in the SF breeding farm may be linked to the small population size, where all the animals were tested. The results show that breeding farms with 50 to 60 animals (CG and CS) have higher genetic diversity than those with only a dozen animals that come from a small number of founding parents, as is the case of the SF breeding farm. Bowland et al. (2001) found, using RAPD markers, that intragroup genetic variability in free living zebras decreased according to population size. Leipoldt et al. (1996) used RAPD markers and found no effect of population size on the genetic variability of Madagascar lemur populations. The analyzed zebra populations varied

Table 1 - Intrapopulation variability among spotted paca breeding farms in southeastern Brazil according to Miller (1997)

\begin{tabular}{lccc}
\hline $\begin{array}{l}\text { Municipality } \\
\text { Sample size } \\
(\mathrm{n})\end{array}$ & $\begin{array}{c}\text { Genetic diversity } \\
\text { Carangola }\end{array}$ & $\begin{array}{c}\text { Polymorphic } \\
\text { loci (\%) P }\end{array}$ \\
São Francisco do Glória & 13 & 0.3589 & 100.00 \\
Castelo & 30 & 0.3244 & 91.66 \\
& & 0.3578 & 98.33
\end{tabular}


from 9 to 2,000 specimens. The lemur populations varied from 6-110 to 60,000 individuals.

In the analysis of molecular variance (AMOVA), $12.55 \%(p<0.0001)$ of the whole variance was linked to differences among breeding farms and $87.45 \%(\mathrm{p}<0.0001)$ of the whole variance was linked to variance within any single breeding farm.

The higher variability among individuals within the populations rather than among populations, agrees with the results reported by Bouzat (2001) in great rhea, Prim et al. (2003) in bullfrogs, Spritze et al. (2003) and Serrano et al. (2003) in naturalized Brazilian cattle, Paiva et al. (2005) in sheep, Albuquerque et al. (2006) in water buffaloes and Godoy et al. (2006) in ostriches.

The principal components analysis (APC), obtained from the Jaccard similarity coefficient among couples of individuals (Figure 1), showed that the groups were well defined in the different breeding farms, with the exception of a few specimens. The first principal component showed the separation between CG and SF and the second showed the separation among SF and CS. A closer relationship was also evident between the animals of CG and SF than to those of CS, with the exception of one animal. Based on these results, it can be said that the genetic groups were separated from each other.

When the breeding farms were compared, the shortest Nei genetic distance $(1973)$ was $0.11766(p<0.00001)$ among the animals from CG and SF. This finding may be linked to the exchange of reproducers that occurs between this two breeding farms, that are a short distance apart (Table 2).

These results show the importance of exchanging reproducers among a higher number of breeding farms and the importance of the possibility of wild animal capture, authorized by IBAMA, in order to preserve the genetic

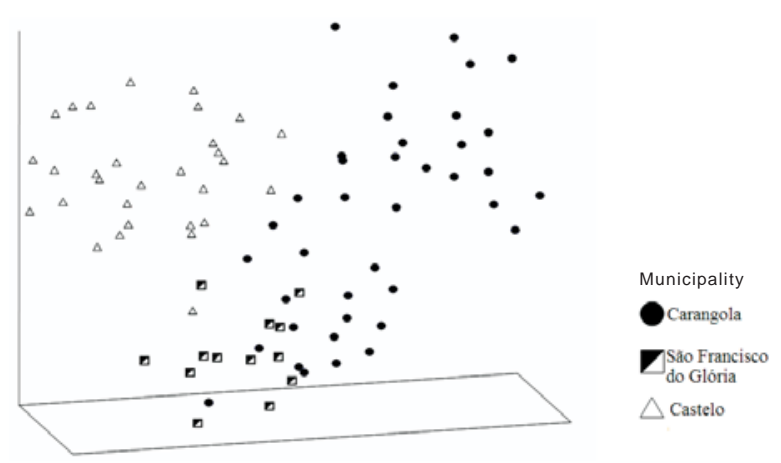

Figure 1 - Principal components analysis (APC) obtained from the Jaccard similarity coefficient among spotted pacas bred in southeastern Brazil.
Table 2 - Distance of Nei among spotted paca breeding farms in southeastern Brazil

\begin{tabular}{lccc}
\hline Municipality & Carangola & São Francisco & Castelo \\
\hline Carangola & 0,00000 & & \\
São Francisco & 0,11766 & 0,00000 & \\
Castelo & 0,12747 & 0,12732 & 0,00000 \\
\hline
\end{tabular}

variety within the breeding farms. The capture of wild animals is allowed by the $6^{\text {th }}$ paragraph, $11^{\text {th }}$ chapter of the IBAMA 118/1997 regulations. As there is no analysis of the population density of free living animals, this activity was not authorized, even before the IBAMA rule 169/2008, that does not mention the subject.

The phenogram shows the grouping of Carangola and São Francisco da Glória as the most similar populations and Castelo as different from those and placed on a different branch (Figure 2). This result confirms that obtained by the PCA (Figure 1) and definitively confirms that the Carangola and São Francisco da Glória populations are more similar. It is consistent with the geographic proximity of the breeding farms and with the exchange of reproducers between these two breeding farms.

We suggest that more studies are carried out, using codominant markers and that more diverse populations are studied.

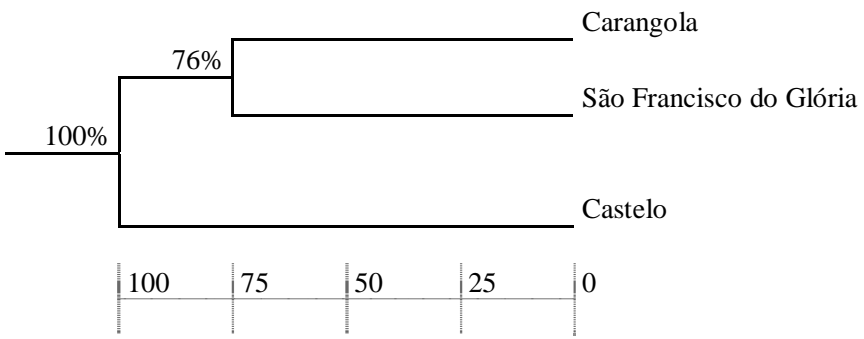

Numeric values at any knot represent the bootstrap values for 1000 repetitions

Figure 2 - Phenogram among spotted paca breeding farms in southeastern Brazil according to the Nei distance (1973) and the UPGMA algorithm.

\section{Conclusions}

The RAPD molecular marker technique served to quantify the among and within genetic variability in spotted paca populations. The populations of the three breeding farms described in this study were separated. The genetic variability inside the spotted paca breeding farms seemed to be influenced by the breeding size, suggesting the importance of the periodic substitution of the captive males. 


\section{References}

ALBUQUERQUE, M.S.M.; EGITO, A.A.; MARQUES, J.R.F. et al. Variabilidade genética de búfalos estimada pela técnica de RAPD. Pesquisa Agropecuária Brasileira, v.41, n.4, p.623-628, 2006.

BOWLAND, A.E.; BISHOP, K.S.; TAYLOR, P.J. et al. Estimation and management of genetic diversity in small populations of plains zebra (Equus quagga) in KwaZulu-Natal, South Africa. Biochemical Systematics and Ecology, v.29, n.6, p.563-583, 2001.

BOUZAT, J.L. The population genetic structure of the greater rhea (Rhea americana) in an agricultural landscape. Biological Conservation, v.99, n.3, p.277-284, 2001.

BRASIL. Lei $n^{\circ} 5.197$, de 3 de janeiro de 1967. Dispõe sobre a proteção à fauna e da outras providências. Diário Oficial da União, Brasília, 5 de janeiro de 1967.

DEUTSCH, L.A.; PUGLIA, L.R.R. Os animais silvestres. Proteção, doenças e manejo. Rio de Janeiro: Globo, 1988. 191p.

GIMENEZ, D.L.; MOTA, L.S.L.S.; CURI, R.A. et al. Análise cromossômica e molecular do javali europeu Sus scrofa scrofa e do suíno doméstico Sus scrofa domesticus. Brazilian Journal of Veterinary Research and Animal Science, v.40, n.2, p.146-154, 2003.

GODOY, L.C.; CARDOZO, R.M.; MORAES, G.V. Avaliação de diversidade genética em subespécies e cruzamento de avestruzes (Struthio camelus) com o uso de marcadores RAPD. Acta Scientiarium. Animal Science, v.27, n.2, p.199-206, 2005.

HADRYS, H.; BALICK, M.; SCHIERWATER, B. Applications of random amplified polymorphic DNA (RAPD) in molecular ecology. Molecular Ecology, v.1, n.1, p.55-63, 1992.

IBAMA Anexos da Instrução Normativa $n^{\circ}$ 169, de 20 de fevereiro de 2008. Diário Oficial da União, Brasília, 22/02/2008, n.36, seção I, p.62-71, 2008b.

IBAMA Fauna. Lista dos criadouros conservacionistas. Disponível em <http://www.ibama.gov.br/fauna/criadouros/ conservacionistas.pdf $>$.Acesso em: 3/6/2006a.

IBAMA Fauna. Lista dos criadouros comerciais. Disponível em $<$ http://www.ibama.gov.br/fauna/criadouros/comerciais.pdf >. Acesso em: 3/6/2006b.

IBAMA Fauna. Lista dos criadouros científicos. Disponível em $<$ http://www.ibama.gov.br/fauna/criadouros/cientificos.pdf >. Acesso em: 3/6/2006c.

IBAMA Instrução Normativa $\mathrm{n}^{\circ}$ 169, de 20 de fevereiro de 2008. Diário Oficial da União, Brasília, 21/02/2008, n.35, seção I, p.58-59, 2008a.

IBAMA Portaria n. ${ }^{\circ} 117$ de 15 de outubro de 1997. Diário Oficial da União, 17/10/1997, seção I, p.26564, 1997a.

IBAMA Portaria n. ${ }^{\circ} 118$ de 15 de outubro de 1997 . Diário Oficial da União, n.200, Brasília, 16/10/1997, seção I, p.23490. Retificada em 17/11/1997. Diário Oficial da União, seção I, p.26564, 1997b.

LANDE, R. Genetics and demography in biological conservation. Science, v.241, n.4872, p.1455-1460, 1988.

LEIPOLDT, M.; SCHLITZ, A.; GANZHORN. J.U. et al. Genetic analysis of Lepilemur mustelinus ruficaudatus population using RAPD markers. In: LOURENÇO, W.R. (Ed.). Biogéographie de Madagascar. Paris: Orstom, 1996. p.267-274. (Actes du Colloque International).

LIMA, R.M.G.; GUIMARAES, S.E.F.; PINHEIRO, L.E.L. Fatores que afetam a amplificação de DNA pela técnica de RAPD (random amplified polymorphic DNA). Arquivo Brasileiro de Medicina Veterinária e Zootecnia, v.50, n.4, p.401-407, 1998.

MACHADO, T.M.M.; MORATA, R.L.; ANTUNES, K.V. et al. Animais silvestres e Zootecnia. Revista Ação Ambiental, v.10, n.35, p.29-31, 2007a.

MACHADO, T.M.M.; GLERIANI, J.M.; LADEIRA, I.R.C. et al. Perfil da criação legalizada de animais silvestres no Brasil. Revista Ação Ambiental, v.10, n.35, p.15-19, 2007b.

MILLER, M.P. [1997]. Tools for population genetics analyses (TFPGA), v.1.3: A Windows program for the analysis of allozyme and molecular population genetic data. Disponível em: <http://www.marksgeneticsoftware.net/tfpga.htm>. Acesso em: 13/11/2008.

MOREIRA, J.R.; MACDONALD, D.W. Técnicas de manejo de capivaras e outros grandes roedores na Amazônia. In: VALLADES-PÁDUA, C.; BODMER, R.E.; WLLEN, J.R.L. (Eds.) Manejo e conservação de vida silvestre no Brasil. Belém: Sociedade Civil Mamirauá, 1997. p.186-213.

NEI, M. Analysis of gene diversity in subdivide populations. Proceedings of the National Academy of Science of the United States of America, v.70, n.12, p.321-323, 1973.

NICHOLAS, F.W. Introdução à genética veterinária. Porto Alegre: Artes Médicas Sul, 1999. 326p.

NOGUEIRA FILHO, S.L.G.; NOGUEIRA, S.S.C. Criação de pacas Agouti paca. Piracicaba: Fundação de Estudos Agrários Luiz de Queiroz, 1999. 70p.

NOGUEIRA FILHO, S.L.G.; NOGUEIRA, S.S.C. Criação comercial de animais silvestres: produção e comercialização da carne e de subprodutos na Região Sudeste do Brasil. Revista Econômica do Nordeste, v.31, n.2, p.188-195, 2000.

ODA, S.H.I.; BRESSAM, M.C.; FREITAS, R.T.F. et al. Composição centesimal e teor de colesterol dos cortes comerciais de capivaras (Hydrochaeris hydrochaeris, L. 1776). Ciência Agrotecnologia, v.28, n.6, p.1344-1351, 2004.

PAIVA, S.R.; SILVÉRIO, V.C.; EGITO, A.A. et al. Genetic variability of the Brazilian hair sheep breeds. Pesquisa Agropecuária Brasileira, v.40, n.9, p.887-893, 2005.

PALEARI, M.A.; MORETTI, V.M.; BERETTA, G. et al. Cured products from different animal species. Meat Science, v.63, n.4, p.485-489, 2003.

PRIM, E.C.P.; PÁDUA, J.T.; BATAUS, L.A.M. Variabilidade genética da rã-touro gigante (Rana catesbeiana) proveniente de populações dos estados de Goiás, Pará e Paraná, criadas em sistema intensivo de cultivo. Ciência Animal Brasileira, v.4, n.1, p.1-6, 2003.

ROMESBURG, C. Cluster analysis for researchers. La Vergne: Lightning Source, 2004. 344p.

SAMBROOCK, J.; FRITSCH, E.F.; MANIATS, T. Molecular cloning: a laboratory manual. 2.ed. New York: Cold Spring Harbor Laboratory Press, 1989. 3v. 626p.

SERRANO, G.M.; EGITO, A.A.; McMANUS, C. et al. Genetic diversity and population structure of Brazilian native bovine breeds. Pesquisa Agropecuária Brasileira, v.39, n.6, p.543-549, 2004.

SNEATH, P.H.A.; SOKAL, R.R. Numerical taxonomy: the principles and practice of numerical classification. San Francisco: W. H. Freeman, 1973. 573p.

SPRITZE, A.; EGITO, A.A.; MARIANTE, A.S. et al. Caracterização genética da raça bovina Crioulo Lageano por marcadores moleculares RAPD. Pesquisa Agropecuária Brasileira, v.38, n.10, p.1157-1164, 2003.

SCHNEIDER, J-M.K.; ROESSLI, D.; EXCOFFIER, L. [2000]. Arlequin, v.2.0: a software for population genetic data analysis. Genebra: Genetics and Biometry Laboratory, University of Geneva, Switzerland. 111p. Disponível em: <http://lgb.unige.ch/arlequin>. Acesso em: 13/11/2008.

STEWART JR., C.N.; EXCOFFIER, L. Assessing population genetic structure and variability using RAPD data: application to Vaccinium macrocarpon (American cranberry). Journal of Evolutionary Biology, v.9, n.2, p.153-171, 1996.

WELSH, J.; McCLELLAND, M. Fingerprinting genomes using PCR with arbitrary primers. Nucleic Acids Research, v.18, n.24, p.7213-7218, 1990.

WEIR, B.S. Genetic data analysis II: methods for discrete population genetics data. Sunderland: Sinauer Associates, 1996. 445p.

WILLIAMS, J.G.K.; KUBELIK, A.R.; LIVAK, K.J. et al. DNA polymorphisms amplified by arbitrary primers are useful as genetics markers. Nucleic Acids Research, v.18, n.22, p.6531-6535, 1990. 